DEPARTMENT OF ACCOUNTING AND FINANCE

\title{
Did Federal Funds Target Rate Changes Affect the Market Value of Insurance Compagnies?
}

Marc J.K. De Ceuster, Jie Li \& Hairui Zhang

\author{
UNIVERSITY OF ANTWERP \\ Faculty of Applied Economics \\ Stadscampus \\ Prinsstraat 13, B.226 \\ BE-2000 Antwerpen \\ Tel. +32(0)3265 4032 \\ Fax +32(0)3 2654799

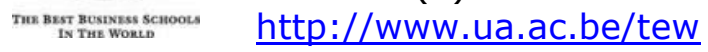




\title{
FACULTY OF APPLIED ECONOMICS
}

\author{
DEPARTMENT OF ACCOUNTING AND FINANCE \\ Did Federal Funds Target Rate Changes Affect the \\ Market Value of Insurance Compagnies?
}

Marc J.K. De Ceuster, Jie Li \& Hairui Zhang

RESEARCH PAPER 2012-027

DECEMBER 2012
University of Antwerp, City Campus, Prinsstraat 13, B-2000 Antwerp, Belgium Research Administration - room B.226 phone: (32) 32654032 fax: (32) 32654799
e-mail: joeri.nys@ua.ac.be

The papers can be also found at our website: www.ua.ac.be/tew (research > working papers) \& www.repec.org/ (Research papers in economics - REPEC)

$D / 2012 / 1169 / 027$ 


\title{
Did Federal Funds Target Rate Changes Affect the Market Value of Insurance Companies?
}

\author{
Marc J.K. De Ceuster ${ }^{a, b,{ }^{*}}$, Jie Li ${ }^{\text {b }}$, Hairui Zhang a,b \\ ${ }^{a}$ Universiteit Antwerpen, Prinsstraat 13, 2000 Antwerp, Belgium \\ ${ }^{\mathrm{b}}$ Antwerp Management School, Sint-Jacobsmarkt 13, 2000 Antwerp, Belgium
}

\begin{abstract}
In this paper, we study the sensitivity of insurance companies' stock returns with respect to expected and unexpected changes in the Federal funds target rate over the period 1988-2007. We confirm Bernanke and Kuttner (2005) that, as stocks in general, insurance stock returns are only sensitive to the unexpected changes in the Federal funds target rate, but not to the expected ones. However, market-adjusted stock returns do only show a reaction for the non-life insurers. For life insurers, there does not seem to be an industry specific effect on their market value. This can be explained by the business models life and nonlife insurers adopt.
\end{abstract}

Keywords: interest rate shocks; insurance companies; Federal funds target rate changes JEL Code: E42, E43, E52, G22

○ Corresponding Author: hairui.zhang@ua.ac.be, Prinsstraat 13, 2000 Antwerp, Belgium. Tel.: +32 326541 07; fax: +3232654064

\footnotetext{
${ }^{1}$ The authors would like to thank Jan Annaert, Anouk Claes and Joseph Plasmans for constructive comments on this paper. The usual disclaimer applies.
} 


\section{Introduction}

Insurers issue contingent claims to a set of policy holders and use the proceeds to purchase a portfolio of assets (Stacking and Babbel (1995)). In order to hedge against interest rate risk, insurers match the durations of their assets and liabilities. The asset-liability mix and the risk management skills largely determine the income generating capacity, the risk sensitivity of the cash flows and hence the market value of the insurer. Mismanagement of the interest rate risk should be taken seriously since it can even lead to the insolvency of the insurance company (Brewer III, Carson, Elyasiani, Mansur and Scott (2007)). Most authors implicitly or explicitly seem to agree with Hodes and Feldblum (1996) and Lee and Stock (2000) that on theoretical grounds, interest rate risk creates a potentially adverse effect on the market value of (financial) companies.

For a sample of banks Flannery and James (1984) empirically confirm that common stock returns are negatively correlated with interest rate changes and that the magnitude of this negative correlation is positively related to the size of the maturity mismatch between assets and liabilities in these banks. Additionally, Chen and Chan (1989) show that the stock returns of banks are most sensitive to positive shocks in interest rates. For insurance companies Doherty and Kang (1988) and Haley (1993) also find that the short-term interest rates have a negative impact on the underwriting premiums for property-liability insurers. Brewer III et al. (2007) confirm that the equity value of life insurance companies is also negatively related to interest rate changes.

Of all interest rate changes, Federal funds target rate (further abbreviated as FFTR) changes are considered to be the most direct monetary policy actions in the U.S. financial markets (Bernanke and Kuttner (2005)). When a new FFTR is set by the Federal Open Market Committee (FOMC), the trading desk of the Federal Reserve (the Desk) buys (sells) government securities to pump up (reduce) the money supply to control the short-term interest rate to meet its target. Understanding how equity markets react to FFTR changes is important for both monetary policy makers and investors. Kuttner (2001) distinguishes anticipated and unanticipated changes (surprises) in the FFTR. He finds that short-term rates (3-month) are sensitive to both anticipated and unanticipated changes whereas long-term rates only response to surprises. The reason is that, according to expectation hypothesis, the long-term rate is determined by the evolution of the short rate. When the market expects a FFTR change, the expectation is embedded in the long-term rate. Only surprises will change the market's expectation on future interest rates.

Using the decomposition in anticipated and unanticipated FFTR changes suggested by Kuttner (2001), Bernanke and Kuttner (2005) find that an unanticipated 25 basis points cut in the FFTR boosts the CRSP 
value-weighted return index by 100 basis points. For the anticipated changes in FFTR, however, no significant impact was found. Due to their lines of activity, financial institutions are likely to be more interest rate sensitive than corporates, which means that their market value can be expected to respond in a more pronounced way to monetary policy actions. While focusing on bank stocks, Yin, Yang and Handorf (2010) confirm Bernanke and Kuttner's (2005) finding that stock returns only respond to unexpected changes in the FFTR. However, it is not clear to what extent, banks or financial institutions in general, are reacting differently than the complete market, since Yin et al. (2010) also show that 25 basis points cut in the FFTR boosts the bank index by 100 basis points, just the same as the response of the complete market. While Bernanke and Kuttner's (2005) finding can be described as a 'market wide' effect, it is not clear whether - at the time of FFTR changes - the returns of financial institutions also exhibit an industry specific component.

Our paper contributes to the existing literature by answering two questions: (1) "Do the results of Bernanke and Kuttner (2005) and Yin et al. (2010) also apply to other segments of the financial industry: the life and non-life insurance companies?" and (2) "To what extent is the market reaction due to FFTR changes, industry specific?" We do not treat the insurance industry as a homogeneous group since life and non-life insurers have different asset-liability balance sheet mixes and a very distinct track record in managing interest rate risk (CAS Committee on Financial Analysis (1991)). ${ }^{2}$ Santomero and Babbel (1997) e.g. argue that only life insurance companies take the interest risk on their liability side seriously. Feldblum (1989) and Lee and Stock (2000) provide several explanations why life and non-life insurers view and treat interest rate risk on their balance sheets differently. ${ }^{3}$

\footnotetext{
${ }^{2}$ Non-life insurance encompasses property and casualty insurance, insurance brokers, reinsurance and full line insurers. We dropped the reinsurance and full line insurers from the sample. In both cases, the degree of interest rate sensitivity was unclear to us due to their mixed portfolio of insurance products.

${ }^{3}$ First, life insurance liabilities are expressed in fixed nominal terms, whereas the casualty insurance liabilities are determined at the settlement date and are subject to inflation risk. Second, life insurers sell long-term policies and invest in long duration fixed income portfolios in order to achieve asset-liability matching. Non-life insurers mainly sell short-term policies requiring - from an asset-liability management perspective - investments in short duration portfolios. Due to the inflation sensitive nature of non-life insurance liabilities, however, non-life insurers have to invest in longer term assets which are inflation sensitive. In periods when the term structure is increasing, the search for higher returns also creates a preference of non-life insurers for long-term bonds. For life-insurers, the duration-matching strategies will not work as expected whenever there are embedded options (Lee and Stock (2000)). Callable assets and puttable liabilities will cause the liability duration to decline substantially, which increases the probability of a negative duration gap. As a consequence, the negative relationship between interest rate changes and equity value is not excluded whenever the hedging strategies performed lack sophistication.
} 
In line with Bernanke and Kuttner (2005) and Yin et al. (2010), we generally find that both life and nonlife stock returns are only sensitive to unexpected changes in the FFTR. This sensitivity does not turn out to be regime dependent in the sense that the magnitude and the direction (i.e. the sign) of FFTR changes do not seem to matter to investors. However, when we examine the market adjusted returns, we find that FFTR changes have an industry specific impact on non-life insurance companies, whereas life insurers response in line with the total market to monetary policy actions.

The remainder of this paper is organized as follows. In Section 2, we present our data and their descriptive statistics. In the subsequent section (Section 3) we formulate our basic regression model. We also advance regression specifications to test the robustness of our basic model with respect to the disclosure transparency, the direction and the magnitude of the changes and FOMC policy reversal. Section 4 discusses our empirical results. Irrespective of the state dependencies introduced, we mainly find negative stock price reaction to unexpected FFTR changes for both life and non-life insurance companies. Section 5 focusses on the industry specific reaction to expected and unexpected interest rate changes. Here we find that only non-life insurers demonstrate industry specific reactions. Finally, we conclude.

\section{Data}

\subsection{The Federal Fund Target Rate Change Days}

Empirical results from Kuttner (2001), Bernanke and Kuttner (2005) and Yin et al. (2011) all show that the market actively anticipate FFTR changes. In this paper, we assess the price reaction of insurance stocks to expected and unexpected changes in the FFTR over the period 1988-2007. 1988 is chosen as the starting year because the Federal funds futures contracts, from which we infer the expected and unexpected changes in interest rates, were launched on the Chicago Board of Trade in October 1988. Our sample period ends in December 2007 because of the substantial change in monetary policy that shifted from adjusting the target rate to a target range which flaws the definition of the actual change. It turns out, however, that even then during some periods in our sample the precise definition of the FFTR change day is ambiguous. Whenever a FOMC meeting took place in the pre-February 1994 period, the market had to guess the change in the FFTR from purchase or selling signals from the Desk since it was not publicly disclosed (Poole and Rasche (2003)). In February 1994, the Federal Reserve changed the FOMC disclosure practice to make monetary policy decisions more transparent. Since then, the FOMC has announced the size and the motivation of each target rate change at the conclusion of its meeting or at a conference call. Notwithstanding the unclear interpretation of the pre-1994 FFTR change day, Kuttner (2001) still considers the date following the 
FOMC meetings as the FFTR change day. A lag of one day reflects the time needed to observe the actions the Desk took. For the post 1994-period the events are the dates of the FOMC meetings. Since some additional target rate changes took place between FOMC meetings, the announcement dates for these (unscheduled) changes were added as 'event dates'. For the 1988-2007 period, a complete list of the FFTR changes defined as described before has been compiled by Kuttner ${ }^{4}$ and reproduced in Yin, et al. (2010 Table 1 and Appendix). During the period under study, 83 changes took place in the FFTR. In addition, 100 meetings did not result in a change, although the market could have expected one. Consequently, 183 FFTR changes are potentially under study.

Since non-life insurers are severely affected by - non-interest rate related - major events such as hurricanes and terrorist attacks, we eliminated the observations summarized in Table 1. These FFTR changes occur within a period of 11 trading days around the listed disasters. Dismissing these FFTR changes, we obtain a 'clean' sample of 178 observation dates. Our results are neither affected by the choice of the 11 day window, nor by the elimination of these observations.

Table 1: FFTR Change Excluded from Our Sample

\begin{tabular}{|c|c|c|}
\hline $\begin{array}{l}\text { FFTR Change } \\
\text { Date }\end{array}$ & Disaster & Loss (billion USD) \\
\hline $8 / 19 / 1992$ & $\begin{array}{l}\text { Hurricane Andrew }(8 / 16 / 1992- \\
8 / 28 / 1992)^{5}\end{array}$ & $\$ 21$ billion on $\mathrm{P} \& \mathrm{C}$ insurers \\
\hline 9/4/1992 & $\begin{array}{l}\text { Hurricane Andrew (8/16/1992 - } \\
8 / 28 / 1992)\end{array}$ & $\$ 21$ billion on $\mathrm{P} \& \mathrm{C}$ insurers \\
\hline 9/17/2001 & 9-11 Terrorist Attacks $(9 / 11 / 2001)^{6}$ & $\begin{array}{l}\$ 40 \text { billion on insurance } \\
\text { companies }\end{array}$ \\
\hline $8 / 10 / 2004$ & Hurricane Charley $(8 / 9 / 2004-8 / 15 / 2004)^{7}$ & $\$ 16$ billion in total \\
\hline \multirow[t]{2}{*}{$9 / 20 / 2005$} & $\begin{array}{l}\text { Hurricane Katrina }(8 / 23 / 2005- \\
8 / 30 / 2005)^{8}\end{array}$ & $\$ 81$ billion on $\mathrm{P} \& \mathrm{C}$ insurers \\
\hline & Hurricane Rita (9/20/2005) ${ }^{9}$ & $\$ 10$ billion in total \\
\hline
\end{tabular}

\footnotetext{
${ }^{4}$ https://www.sugarsync.com/pf/D64142 026413 79544. Last visited on December 6, 2010.

5 http://en.wikipedia.org/wiki/Hurricane Andrew. Last visited on December 6, 2010.

${ }^{6}$ http://www.iags.org/costof911.html. Last visited on December 6, 2010.

${ }^{7}$ http://en.wikipedia.org/wiki/Hurricane_Charley. Last visited on December 6, 2010.

8 http://en.wikipedia.org/wiki/Hurricane_Katrina. Last visited on December 6, 2010.

${ }_{9}$ http://en.wikipedia.org/wiki/Hurricane_Rita. Last visited on December 6, 2010.
} 


\subsection{The expected and unexpected interest rate changes}

It is well known that stock returns especially react to unexpected information shocks while expected information will not make stock returns change substantially. Since we want to investigate the impact of FFTR changes, the 30-day Federal funds futures contracts become a natural candidate to predict expected rate changes. Krueger and Kuttner (1996) show that month-to-month changes in the Federal funds rate are predictable using the 1-month Federal funds futures rate. Following Krueger and Kuttner (1996), Kuttner (2001), Bernanke and Kuttner (2005), and Yin et al. (2010), we also define the unexpected interest rate change, $\Delta r_{i}^{u}$, as

$$
\Delta r_{i}^{u}=\frac{m}{m-p}\left(f_{s, p}^{0}-f_{s, p-1}^{0}\right)
$$

where $m$ is the number of days in month $s$ when event $i$ actually occurs, $p$ is the number of days from the beginning of that month to the event day, and $f_{s, p}^{0}$ is the Federal funds futures rate on day $p$. The expected target rate change $\Delta \tilde{r}_{i}^{e}$ is the difference between the actual target rate change $\Delta \tilde{r}_{i}$ and $\Delta r_{i}^{u}$.

The cumulative expected and unexpected components from the changes in the Federal funds rate are presented in Figure 1. The former seems to mean revert around zero. The latter shows a steady downward drift over the period. A complete table with the numerical values of $\Delta \tilde{r}_{i}^{e}$ and $\Delta r_{i}^{u}$ can be found in Yin et al. $(2010$ - Table 1).

Figure 1: Decomposition of the cumulative Federal fund target rate changes (in bps)

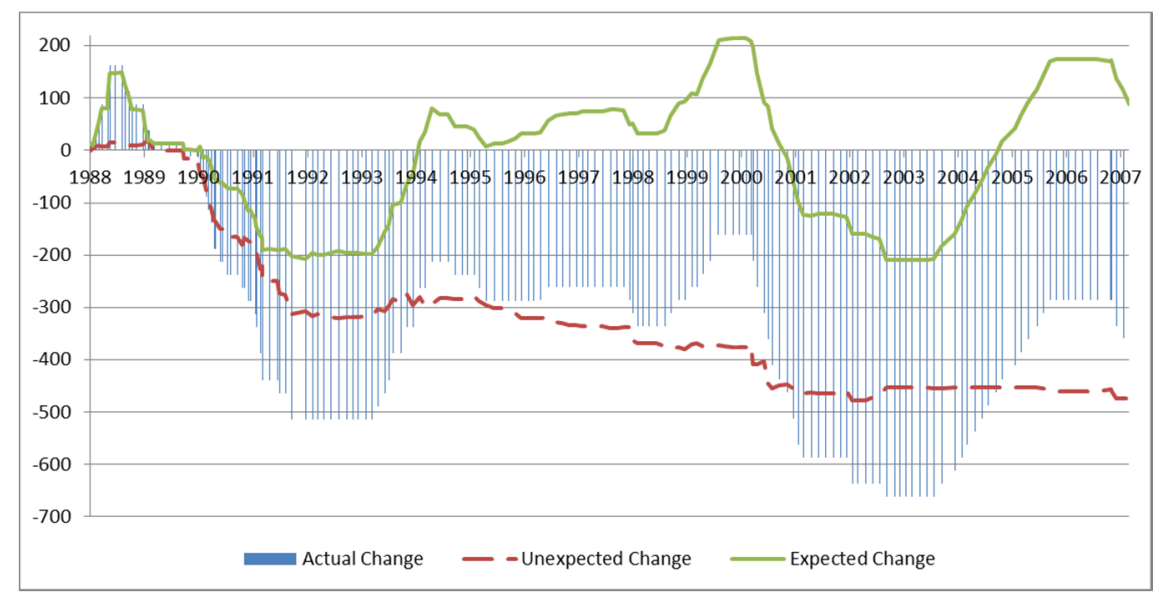

Note: This figure plots the cumulative Federal fund target rate change over time and the decomposed unexpected and expected changes over the period from October 1988 to December 2007, covering 178 events. 
Table 2 presents the descriptive statistics of the expected and unexpected changes in the FFTR. The mean of the surprises is -2.66 basis points, compared to 0.50 basis points of the corresponding expected changes. As anticipated, the expected changes moves around zero, which implies the market expectation is mean reverting. The low lag-1 autocorrelation -0.04 of surprises is evidence that the series is indeed full of 'surprises'.

Table 2 Descriptive Statistics of the Expected and Unexpected Changes in the Federal Funds Target Rate (in bps)

\begin{tabular}{l|c|c}
\hline & $\Delta r^{u}$ & $\Delta \tilde{r}^{e}$ \\
\hline Mean & -2.66 & 0.50 \\
Standard Deviation & 9.24 & 18.13 \\
Minimum & -43 & -56 \\
Maximum & 15 & 61 \\
No. of Obs. & 178 & 178 \\
$\rho(1)$ & -0.04 & 0.59 \\
\hline Note: The FFTR change dates are determined by the announcements made by the Federal Open Market Committee (FOMC) on \\
the FFTR change or the day when the market could react to the announcement. They are the same as Kuttner's (See Footnote 2) \\
except for the five dates listed in Table 1. $\rho(1)$ reports lag l autocorrelation of each series.
\end{tabular}

\subsection{The FFTR change day return of insurance firms}

Based on the Dow Jones Industry Categorization Benchmark, we selected all U.S. life and non-life insurers that were listed on NASDAQ, NYSE and AMEX. We collected the daily stock returns from Thompson Datastream covering the period between October 1988 and December 2007. Both active and "dead" insurers up to December 2007 were obtained to avoid survivorship bias. Our final sample consists of 70 life insurance companies and 147 non-life insurers.

For each FFTR change day, two equally-weighted portfolios are formed for life and non-life insurance companies, in which the selected stocks must have at least 11 days with continuous trading around the FFTR change day to alleviate the influence of thin trading and liquidity premiums.

\section{Hypothesis formulation}

\subsection{Do stocks only react to information shocks?}

Monetary policy has an immediate impact on the short term rates which is expected to be transmitted to the whole yield curve. Under the expectation hypothesis, Kuttner (2001) shows that long-term rates embed the anticipated FFTR changes and consequently, they will hardly respond to them. Monetary policy induced 
changes in the yield curve, will subsequently also affect stock prices. The efficient market hypothesis predicts that stock prices should incorporate all known and expected information immediately and should only react to unexpected information shocks. Chen, Mohan, and Steiner (1999), Kuttner (2001), Guo (2004), Bernanke and Kuttner (2005), and Yin et al. (2010) provide supporting evidence in the sense that stock prices only react to unexpected monetary policy actions, as expected monetary policy actions, through longterm rates, are already taken into account by the market. We follow the approach of Bernanke and Kuttner (2005) and Yin et al. (2010) to assess the impact of changes in the FFTR on the stock returns of insurance companies. Bernanke and Kuttner (2005) and Yin et al. (2010) regress the (raw) equity returns on the anticipated and the unanticipated interest rate changes,

$$
R_{i}=\alpha+\beta_{u} \Delta r_{i}^{u}+\beta_{e} \Delta \tilde{r}_{i}^{e}+\varepsilon_{i},
$$

where $R_{i}$ is the portfolio return for event $i, \Delta r_{i}^{u}$ is the unexpected interest rate change, and $\Delta \tilde{r}_{i}^{e}$ is the expected interest rate change. We test

HIa: $\beta_{u} \geq 0$;

$H 1 b: \beta_{e}=0$.

\subsection{Does disclosure transparency affect the (measurement of) the interest rate sensitivity?}

Chen and Chan (1989) postulate that the relationship between interest rate changes and stock returns of financial institutions has not been constant over time, a finding which they attributed to regime switches in monetary policy. The change in the FOMC disclosure practice in February 1994 is likely to have changed the interest rate sensitivity or at least the possibility to measure the interest rate sensitivity. The new disclosure practice allows the FOMC to convey its intentions to the market in a more timely fashion, which reduces uncertainty and volatility (Lobo (2002)). Nosal (2001) also points out that there are fewer unexpected interest rate changes after February 1994, which is confirmed by Poole and Rasche (2003) as well. Although the empirical results provided by Bernanke and Kuttner (2005) and Yin et al. (2010) did not find strong support for the conjecture that the improved transparency had an impact on stock returns, we want to test whether insurance companies respond differently.

Assuming $D_{y}=1$ for post-February 1994 events, and 0 otherwise, using regression Eq. (3),

$$
R_{i}=\alpha+\beta_{u} \Delta r_{i}^{u}+\beta_{y} D_{y} \Delta r_{i}^{u}+\beta_{e} \Delta \tilde{r}_{i}^{e}+\varepsilon_{i}
$$

we will test:

$H 2 a: \beta_{e}=0$ i.e. whether the expected changes have a significant effect on the insurer's stock returns; 
$H 2 b: \beta_{y}=0$ i.e. whether the post-February 1994 events exhibit a different interest rate sensitivity compared to the pre-February 1994 events;

$H 2 c: \beta_{u}=\beta_{y}=0$. i.e. whether the impact of the unexpected changes is significantly different from zero.

We test $H 2 a$ and $H 2 b$ with a $t$-test. $H 2 c$ is tested using an $F$-test.

\subsection{Are there other state dependencies?}

Motivated by Flannery and James (1984), Bernanke and Kuttner (2005), and Yin et al. (2010), it is also of interest to further explore (potential) state dependencies of the stock returns of insurance companies in various economic contexts. We want to examine:

- whether insurance stock returns react differently to an increase or a decrease of the adjustments of FFTR;

- whether insurance stock returns react more pronounced to a large target rate change (in magnitude) than to a small one;

- whether insurance stock returns react more pronounced to a target rate change signaling a policy reversal by the Federal Reserve.

Assuming the dummy variable $D_{d}=1$ if the target rate change of event $i$ is negative, and 0 otherwise, we regress

$$
R_{i}=\alpha+\beta_{u} \Delta r_{i}^{u}+\beta_{d} D_{d} \Delta r_{i}^{u}+\beta_{e} \Delta \tilde{r}_{i}^{e}+\varepsilon_{i},
$$

to test whether there is an asymmetric effect of changes in the FFTR on insurance stocks that insurance stock returns react differently to an increase or a decrease of the adjustments of FFTR (H3: $\beta_{d}=0$ ).

The fourth hypothesis conjectures that a large target rate change in the FFTR has a more pronounced effect on insurance stock returns. This we test by regressing,

$$
R_{i}=\alpha+\beta_{u} \Delta r_{i}^{u}+\beta_{s} D_{s} \Delta r_{i}^{u}+\beta_{e} \Delta \tilde{r}_{i}^{e}+\varepsilon_{i},
$$

where the dummy variable $D_{s}=1$ if the absolute value of the target change of event $i$ is greater than the mean of the absolute value of all the surprises, and 0 otherwise ( $\left.\mathrm{H} 4: \beta_{s}=0\right)$.

Finally, the impact of policy reversals in the FFTR is tested using the regression equation, 


$$
R_{i}=\alpha+\beta_{u} \Delta r_{i}^{u}+\beta_{p} D_{p} \Delta r_{i}^{u}+\beta_{e} \Delta \tilde{r}_{i}^{e}+\varepsilon_{i},
$$

where the dummy variable $D_{p}=1$ if the change of event $i$ represents a policy reversal, and 0 otherwise (H5: $\beta_{p}=0$ ). Following Bernanke and Kuttner (2005), we assume that a policy reversal occurs whenever there is a change of direction in the FFTR adjustment.

\section{Results}

\subsection{Do stocks only react to information shocks?}

Table 3 summarizes the OLS results based on Eq.(2). Consistent with Chen et al. (1999), Kuttner (2001), Guo (2004), Bernanke and Kuttner (2005) and Yin et al. (2010), stock returns of both insurer categories do not seem to significantly react to the expected changes in the target rate. The reaction to the unexpected change in the FFTR carries a negative sign for each insurance category, but only for life insurers this relationship is significant from a statistical point of view. A 1-basis point increase in the unexpected interest rate changes will lower the stock returns of life insurers by 3.40 basis points. Although the explanatory power of this relationship is extremely low, the $F$-statistics of the life insurers are significant. Our results provide evidence that life insurers are sensitive to surprises in monetary policy actions. On contrary, we are not able to confirm that the stock returns of non-life insurers are strongly affected by FFTR changes.

Table 3 Interest Rate Sensitivity of Insurance Companies over the Period 1988 - 2007

\begin{tabular}{c|ccc|cc}
\hline & \multicolumn{3}{|c|}{ Life } & \multicolumn{2}{c}{ Non-life } \\
\hline$\alpha$ & coef. & t-stat & coef. & $t$-stat \\
$\beta_{u}$ & 17.29 & 1.84 & $18.55^{*}$ & 2.91 \\
$\beta_{e}$ & $-3.40^{*}$ & & -3.40 & -1.01 & -1.48 \\
$A d j R^{2}$ & 0.37 & & 0.72 & -0.18 & -0.52 \\
$n$ & & $5.13 \%$ & & \multicolumn{2}{c}{$0.54 \%$} \\
$F$ & & 178 & & \multicolumn{2}{c}{178} \\
\hline
\end{tabular}

Note: This table shows the regression results of the equally-weighted portfolios on unexpected $\left(\Delta r^{u}\right)$ and expected ( $\left.\Delta \tilde{r}^{e}\right)$ components of the change in the Federal funds target rate for two sub-industries. The estimates, their t-stats, the adjusted $R^{2}$, the number of observations (n), and the F-test results for significance of all coefficients are reported. Insurance companies are categorized using the Dow Jones ICB classification. The sample runs from October 1988 to December 2007, totaling 178 events. The coefficients are expressed in basis points. * means significance at the $95 \%$ confidence interval. 


\subsection{Does disclosure transparency affect the interest rate sensitivity?}

Table 4 presents the empirical results showing the impact of the transparency improvement in 1994. For none of the sub-industries $H 2 a$, the hypothesis that $\beta_{e}$ is zero, can be rejected. In line with Bernanke and Kuttner (2005) and Yin et al. (2010), we do not find statistical evidence that the stock market reacts to expected interest rate changes. For each of the industries the year dummy, $\beta_{y}$, is significantly negative at the $95 \%$ confidence interval. This evidence indicates that the unexpected target rate changes have a more profound (negative) impact on stock returns after the monetary policy changes. The joint hypothesis that $\beta_{u}$ and $\beta_{y}$ simultaneously are different from zero, leads us to conclude that unexpected interest rate changes are significantly negatively impacting stock returns. The major conclusion is obvious. The change in disclosure policy has a significant impact on the interest rate sensitivity of stock returns. The market is more involved in anticipating FFTR changes after February 1994. The vague disclosures in the pre-February 1994 period hampered the market to process the aims of monetary policy makers efficiently. Our results confirm the finding of Nosal (2001), Lobo (2002) and Poole and Rasche (2003) that the 'new' disclosure practice improved transparency of monetary policy and made market participants better informed parties.

Table 4 Interest Rate Sensitivity of Insurance Industry over the Period 1988 - 2007 (Year 1994 Dummy)

\begin{tabular}{c|ccc|ccc}
\hline & \multicolumn{3}{|c|}{ Life } & \multicolumn{3}{c}{ Non-life } \\
\hline & coef. & t-stat & $F_{D_{y}}$ & coef. & t-stat & $F_{D_{y}}$ \\
\hline$\alpha$ & $18.77^{*}$ & 2.02 & & $19.75^{*}$ & 3.13 & \\
$\beta_{u}$ & -1.58 & -1.19 & & 0.47 & 0.52 & $4.26^{*}$ \\
$\beta_{y}$ & $-3.81^{*}$ & -2.04 & $8.21^{*}$ & $-3.09^{*}$ & -2.45 & \\
$\beta_{e}$ & 0.37 & 0.73 & & -0.18 & -0.53 & \\
\hline Adj.R & \multicolumn{3}{|c|}{$6.82 \%$} & & $3.32 \%$ & 178 \\
$n$ & & 178 & & $3.03^{*}$ & \\
$F$ & & $5.32^{*}$ & & & \\
\hline
\end{tabular}

Note: This table shows the regression results of the equally-weighted portfolios on unexpected $\left(\Delta r^{u}\right)$ and expected $\left(\Delta \tilde{r}^{e}\right)$ components of the change in the Federal funds target rate with a dummy variable $D_{y}$ to isolate the impact of the change in the way the Federal Reserve announces changes in the funds target rate. The dummy variable $D_{y}$ is set to 1 for the events after February 1994 and 0 otherwise. The estimates, their $t$-stats, the adjusted $R^{2}$, the number of observations $(n)$, the joint $F$-test $\left(F_{D_{y}}\right.$ ) on $\beta_{u}$ and $\beta_{y}$ and the $F$-test for significance of all coefficients are reported. Insurance companies are categorized using the Dow Jones ICB classification. The sample runs from October 1988 to December 2007, totaling 178 events. The coefficients are expressed in basis points. * means significance at the $95 \%$ confidence interval. 


\subsection{Are there other state dependencies?}

Recall that we also want to examine: (1) whether insurance stock returns react differently to an increase or a decrease of the adjustments of FFTR (H3), (2) whether insurance stock returns react more pronounced to a large target rate change (in magnitude) than a small target rate change (H4), and (3) whether insurance stock returns react more pronounced to a target rate change signaling a policy reversal by the Federal Reserve (H5).

Table 5 summarizes the impact of the direction of target rate changes on stock returns over the period from October 1988 to December 2007 (Panel A) and over the two sub-samples split by the change in disclosure practice in February 1994 (panels B and C). In comparing the panels, it becomes clear that the events during the 1988-1994 period cannot be considered to be 'proper' or 'clean' events. The market had to make inferences based on its observations of the transactions made by the Desk. Panel C makes clear that this is probably due to the ambiguity around the event that the market did not utilize information in monetary policy actions efficiently. The regression adjusted $R^{2}$ s reveal that the results of the overall period are dominated by the 1994-2007 period.

With respect to the unexpected changes, the results in Panel B are again not significant. Panel C, on the contrary, shows that the unexpected interest rate changes have a significantly negative impact on the stock returns (joint test on $\beta_{u}$ and $\beta_{d}$ ). The impact of negative changes, however, is not significant. One can observe that the $F$-stat for the 1994-2007 period for non-life insurers is not significant at the $95 \%$ confidence interval. The results of Panel A are again blurred by the ambiguity of the events in the 1988-1994 period. In conclusion, we do not find evidence in favor of a directional effect of the target rate changes on the stock returns.

The impact of the magnitude of the target rate changes on the stock returns is tested using regression Eq. (5) and is documented in Table 6. The dummy variable $D_{s}$ is set to 1 if the absolute value of the target rate change is greater than the mean of the absolute target rate changes and 0 otherwise. We confirm the overall insignificance of the coefficient on the expected shocks. The results indicate that none of the sub-industries are strongly affected by target rate changes neither before nor after February 1994. 
Table 5 Interest Rate Sensitivity of Insurance Companies (Direction Dummy)

\begin{tabular}{|c|c|c|c|c|c|c|}
\hline \multicolumn{7}{|c|}{ Panel A 1988 - 2007} \\
\hline & \multicolumn{3}{|c|}{ Life } & \multicolumn{3}{|c|}{ Non-life } \\
\hline & coef. & $t$-stat & $F_{D_{d}}$ & coef. & $t$-stat & $F_{D_{d}}$ \\
\hline$\alpha$ & 15.24 & 1.60 & \multirow{4}{*}{$6.53^{*}$} & $18.98^{*}$ & 2.92 & \multirow{4}{*}{1.16} \\
\hline$\beta_{u}$ & -1.03 & -0.46 & & -1.50 & -0.98 & \\
\hline$\beta_{d}$ & -2.95 & -1.18 & & 0.62 & 0.36 & \\
\hline$\beta_{e}$ & 0.39 & 0.76 & & -0.18 & -0.53 & \\
\hline $\operatorname{adj} R^{2}$ & \multicolumn{3}{|c|}{$5.34 \%$} & \multicolumn{3}{|c|}{$0.05 \%$} \\
\hline$n$ & \multicolumn{3}{|c|}{178} & \multicolumn{3}{|c|}{178} \\
\hline$F$ & \multicolumn{3}{|c|}{$4.33^{*}$} & \multicolumn{3}{|c|}{1.03} \\
\hline
\end{tabular}

\begin{tabular}{|c|c|c|c|c|c|c|}
\hline \multicolumn{7}{|c|}{ Panel B 1988 - 1994} \\
\hline & \multicolumn{3}{|c|}{ Life } & \multicolumn{3}{|c|}{ Non-life } \\
\hline & coef. & $t$-stat & $F_{D_{d}}$ & coef. & $t$-stat & $F_{D_{d}}$ \\
\hline$\alpha$ & 1.56 & 0.09 & \multirow{4}{*}{0.80} & 19.12 & 1.81 & \multirow{4}{*}{0.48} \\
\hline$\beta_{u}$ & 3.49 & 0.61 & & 0.89 & 0.26 & \\
\hline$\beta_{d}$ & -5.32 & -0.87 & & -0.03 & -0.01 & \\
\hline$\beta_{e}$ & -1.33 & -1.08 & & -1.23 & -1.71 & \\
\hline $\operatorname{adj} R^{2}$ & \multicolumn{3}{|c|}{$0.97 \%$} & \multicolumn{3}{|c|}{$0.30 \%$} \\
\hline$n$ & \multicolumn{3}{|c|}{63} & \multicolumn{3}{|c|}{63} \\
\hline$F$ & \multicolumn{3}{|c|}{1.20} & \multicolumn{3}{|c|}{1.06} \\
\hline
\end{tabular}

\begin{tabular}{|c|c|c|c|c|c|c|}
\hline \multicolumn{7}{|c|}{ Panel C 1994-2007 } \\
\hline & \multicolumn{3}{|c|}{ Life } & \multicolumn{3}{|c|}{ Non-life } \\
\hline & coef. & $t$-stat & $F_{D_{d}}$ & coef. & $t$-stat & $F_{D_{d}}$ \\
\hline$\alpha$ & 19.90 & 1.81 & \multirow{4}{*}{$9.94^{*}$} & $18.07 *$ & 2.21 & \multirow{4}{*}{$3.92^{*}$} \\
\hline$\beta_{u}$ & -1.91 & -0.82 & & -2.07 & -1.19 & \\
\hline$\beta_{d}$ & -5.24 & -1.84 & & -1.00 & -0.48 & \\
\hline$\beta_{e}$ & 0.73 & 1.34 & & 0.07 & 0.17 & \\
\hline $\operatorname{adj} R^{2}$ & \multicolumn{3}{|c|}{$12.99 \%$} & \multicolumn{3}{|c|}{$4.13 \%$} \\
\hline$n$ & \multicolumn{3}{|c|}{115} & \multicolumn{3}{|c|}{115} \\
\hline$F$ & \multicolumn{3}{|c|}{$6.67 *$} & \multicolumn{3}{|c|}{2.64} \\
\hline
\end{tabular}

Note: This table shows the regression results of the equally-weighted portfolios on unexpected $\left(\Delta r^{u}\right)$ and expected ( $\left.\Delta \tilde{r}^{e}\right)$ components of the change in the Federal funds target rate with a dummy variable $D_{d}$ to identify the impact of the direction of target rate changes. The dummy variable $D_{d}$ is set to 1 for a negative actual change in the Federal funds target rate, and 0 otherwise. The estimates, their t-stats, the adjusted $R^{2}$, the number of observations $(n)$, the joint $F$-test $\left(F_{D_{d}}\right)$ on $\beta_{u}$ and $\beta_{d}$ and the F-test for significance of all coefficients are reported. Insurance companies are categorized using the Dow Jones ICB classification. The sample in Panel A runs from October 1988 to December 2007, totaling 178 events. The sub-sample in Panel B runs from October 1988 to January 1994, totaling 63 events. The sub-sample in Panel C runs from February 1994 to December 2007, totaling 115 events. The coefficients are expressed in basis points. * means significance at $95 \%$ confidence interval. 
Table 6 Interest Rate Sensitivity of Insurance Companies (Size Dummy)

\begin{tabular}{|c|c|c|c|c|c|c|}
\hline 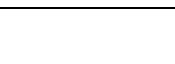 & & Life & & & Von-life & \\
\hline & coef. & $t$-stat & $F_{D_{s}}$ & coef. & $t$-stat & $F_{D_{s}}$ \\
\hline$\alpha$ & 17.03 & 1.82 & \multirow{4}{*}{$6.72 *$} & $18.46^{*}$ & 2.89 & \multirow{4}{*}{1.33} \\
\hline$\beta_{u}$ & 0.18 & 0.06 & & 0.26 & 0.13 & \\
\hline$\beta_{s}$ & -4.10 & -1.31 & & -1.45 & -0.68 & \\
\hline$\beta_{e}$ & 0.55 & 1.05 & & -0.11 & -0.32 & \\
\hline $\operatorname{adj} R^{2}$ & & $5.53 \%$ & & & $0.24 \%$ & \\
\hline$n$ & & 178 & & & 178 & \\
\hline$F$ & & $4.45^{*}$ & & & 1.14 & \\
\hline \multicolumn{7}{|c|}{ Panel B 1988 - 1994} \\
\hline & & Life & & & Von-life & \\
\hline & coef. & $t$-stat & $F_{D_{s}}$ & coef. & $t$-stat & $F_{D_{s}}$ \\
\hline$\alpha$ & 3.96 & 0.23 & \multirow{4}{*}{0.62} & 18.82 & 1.83 & \multirow{4}{*}{0.49} \\
\hline$\beta_{u}$ & 2.59 & 0.41 & & 1.52 & 0.41 & \\
\hline$\beta_{s}$ & -4.31 & -0.64 & & -0.73 & -0.18 & \\
\hline$\beta_{e}$ & -1.16 & -0.91 & & -1.19 & -1.60 & \\
\hline $\operatorname{adj} R^{2}$ & & $0.38 \%$ & & & $0.35 \%$ & \\
\hline$n$ & & 63 & & & 63 & \\
\hline$F$ & & 1.08 & & & 1.07 & \\
\hline
\end{tabular}

\begin{tabular}{|c|c|c|c|c|c|c|}
\hline \multicolumn{7}{|c|}{ Panel C $1994-2007$} \\
\hline & \multicolumn{3}{|c|}{ Life } & \multicolumn{3}{|c|}{ Non-life } \\
\hline & coef. & $t$-stat & $F_{D_{s}}$ & coef. & $t$-stat & $F_{D_{s}}$ \\
\hline$\alpha$ & $23.83^{*}$ & 2.18 & \multirow{4}{*}{$9.97 *$} & $19.25 *$ & 2.39 & \multirow{4}{*}{$4.67^{*}$} \\
\hline$\beta_{u}$ & -0.14 & -0.04 & & -0.07 & -0.03 & \\
\hline$\beta_{s}$ & -6.58 & -1.86 & & -3.31 & -1.27 & \\
\hline$\beta_{e}$ & 0.98 & 1.75 & & 0.20 & 0.48 & \\
\hline $\operatorname{adj} R^{2}$ & \multicolumn{3}{|c|}{$13.02 \%$} & \multicolumn{3}{|c|}{$5.31 \%$} \\
\hline$n$ & \multicolumn{3}{|c|}{115} & \multicolumn{3}{|c|}{115} \\
\hline$F$ & \multicolumn{3}{|c|}{$6.69 *$} & \multicolumn{3}{|c|}{3.13} \\
\hline
\end{tabular}

Note: This table shows the regression results of the equally-weighted portfolios on unexpected $\left(\Delta r^{u}\right)$ and expected ( $\left.\Delta \tilde{r}^{e}\right)$ components of the change in the Federal funds target rate with a dummy variable $D_{\text {s }}$ to identify the impact of the magnitude of target rate changes. The dummy variable $D_{s}$ is set to 1 if the absolute value of the target rate change is greater than the mean of the absolute target rate changes, and 0 otherwise. The estimates, adjusted $R^{2}$, number of observations $(n)$, the joint $F$-test ( $\left.F_{D_{S}}\right)$ on $\beta_{u}$ and $\beta_{s}$ and the F-test for significance of all coefficients are reported. Insurance companies are categorized using the Dow Jones ICB classification. The sample in Panel A runs from October 1988 to December 2007, totaling 178 events. The sub-sample in Panel B runs from October 1988 to January 1994, totaling 63 events. The sub-sample in Panel C runs from February 1994 to December 2007, totaling 115 events. The coefficients are expressed in basis points. * means significance at 95\% confidence interval. 
Table 7 Interest Rate Sensitivity of Insurance Companies (Policy Reversal Dummy)

\begin{tabular}{cccc|ccc}
\hline & \multicolumn{7}{c}{ Panel A 1988-2007 } & \multicolumn{3}{c}{ Non-life } \\
\cline { 2 - 6 }$\alpha$ & coef. & Life & $F_{D_{p}}$ & coef. & t-stat & $F_{D_{p}}$ \\
\cline { 2 - 6 }$\beta_{u}$ & 17.54 & 1.89 & & $18.74^{*}$ & 2.97 & \\
$\beta_{p}$ & $-2.79^{*}$ & -2.67 & & -0.53 & -0.75 & \\
$\beta_{e}$ & -5.49 & -1.87 & $7.84^{*}$ & $-4.28^{*}$ & -2.15 & $3.54^{*}$ \\
AdjR & 0.41 & 0.80 & & -0.15 & -0.44 & \\
$n$ & & $6.47 \%$ & & & $2.57 \%$ & \\
$F$ & & 178 & & & 2.55 & \\
\end{tabular}

\begin{tabular}{|c|c|c|c|c|c|c|}
\hline \multicolumn{7}{|c|}{ Panel B 1988 - 1994} \\
\hline & \multicolumn{3}{|c|}{ Life } & \multicolumn{3}{|c|}{ Non-life } \\
\hline & coef. & t-stat & $F_{D_{p}}$ & coef. & t-stat & $F_{D_{p}}$ \\
\hline$\alpha$ & 4.320 & 0.45 & \multirow{4}{*}{0.63} & 18.73 & 1.83 & \multirow{4}{*}{0.54} \\
\hline$\beta_{u}$ & -1.382 & -0.91 & & 0.85 & 0.96 & \\
\hline$\beta_{p}$ & 18.920 & 0.60 & & 4.95 & 0.27 & \\
\hline$\beta_{e}$ & -1.581 & -1.24 & & -1.28 & -1.72 & \\
\hline $\operatorname{Adj} R^{2}$ & & $0.30 \%$ & & & $0.42 \%$ & \\
\hline$n$ & & 63 & & & 63 & \\
\hline$F$ & & 1.06 & & & 1.09 & \\
\hline
\end{tabular}

\begin{tabular}{cccc|ccc}
\hline \multicolumn{1}{c}{ Panel C 1994-2007 } & \multicolumn{3}{c}{ Lon-life } \\
\cline { 2 - 6 } & coef. & t-stat & $F_{D_{p}}$ & coef. & $t$-stat & $F_{D_{p}}$ \\
\cline { 2 - 6 }$\alpha$ & $22.03^{*}$ & 2.00 & & $18.25^{*}$ & 2.27 & \\
$\beta_{u}$ & $-4.53^{*}$ & -2.94 & & $-2.06^{*}$ & -1.83 & \\
$\beta_{p}$ & -3.92 & -1.27 & $9.23^{*}$ & -2.93 & -1.30 & $4.88^{*}$ \\
$\beta_{e}$ & 0.74 & 1.35 & & 0.08 & 0.21 & \\
AdjR & & $11.61 \%$ & & $5.37 \%$ & \\
$n$ & & 115 & & 115 & \\
$F$ & & $5.99^{*}$ & & & $3.16^{*}$ & \\
\hline
\end{tabular}

Note: This table shows the regression results of the equally-weighted portfolios on unexpected ( $\left.\Delta r^{u}\right)$ and expected ( $\left.\Delta \tilde{r}^{e}\right)$ components of the change in the Federal funds target rate with a dummy variable $D_{p}$ to identify the impact of the policy reversal on stock returns. The dummy variable $D_{p}$ is set to 1 if the change in FFTR represents a policy reversal, and 0 otherwise. The estimates, adjusted $R^{2}$, number of observations ( $\left.n\right)$, the joint F-test ( $\left.F_{D_{P}}\right)$ on $\beta_{u}$ and $\beta_{p}$ and the F-test for significance of all coefficients are reported. Insurance companies are categorized using the Dow Jones ICB classification. The sample in Panel A runs from October 1988 to December 2007, totaling 178 events. The sub-sample in Panel B runs from October 1988 to January 1994, totaling 63 events. The sub-sample in Panel C runs from February 1994 to December 2007, totaling 115 events. The coefficients are expressed in basis points. * means significance at $95 \%$ confidence interval. 
Table 7 summarizes the regression results of stock returns against the target rate changes with a policy reversal dummy. Once more the results of Panel B are much less convincing than those of Panel C. The lack of precision in defining the event does not allow us to make a correct inference over the 1988-1994 period. The 1994-2007 period shows strong and convincing evidence of the negative impact of unexpected changes in the target rate on the stock returns of all insurers. We can explain more the variation for the life insurers (11.61\%). For the non-life insurers, we only explain 5.37\%.

Overall, we do not find profound state dependencies of insurance stock returns on target rate changes. The evidence here is consistent with existing literature. Based on aggregate stock returns, Bernanke and Kuttner (2005) were not able to find any state dependencies either. Based on bank stock returns, Yin et al. (2010) only reveal significant state dependency of policy reversals. We draw the conclusion that the insurance companies in our sample behaved in a very similar way as the banks in their study.

\section{Industry Specific Interest Rate Risk}

Surprises in FFTR changes have an immediate impact on the short end of the yield curve. These surprises affect both the whole market as measured by a composite stock index (Bernanke and Kuttner (2005)) and portfolios of bank stocks (Yin et al. (2010)). Previous research, however, was not able to determine to what extent the market reaction due to FFTR changes, was industry specific. Our baseline regression presented in Eq. (2) captures both the common (i.e. market) reaction to FFTR changes as well as the 'idiosyncratic' (read the 'industry specific') part. In other words, it is not clear whether insurance companies react differently to FFTR changes than the average US corporate. Take the banking industry e.g. Yin et al. (2010) fail to disentangle these components, even though their results show that bank stocks react to surprises in FFTR changes in an extremely close way to the general stock market.

In order to check the industry specific sensitivity of FFTR changes, we run regression Eqs. (2) - (6) on the 'market-model adjusted abnormal returns' for both life and non-life insurers. We choose an estimation window of 32 days (day -35 to day -3 with respect to the event) and use the S\&P 500 index as the market index to calculate market-model adjusted abnormal return on each event date. ${ }^{10}$ To avoid contamination of overlapping events, we only choose events that occurred at least 40 days after their preceding event. In this case, our sample reduced to 113 out of 178 events for life insurance companies, and 114 out of 178 events

\footnotetext{
${ }^{10}$ We check the results based on alternative estimation windows, e.g. 40 to 5 days before the event, 35 to 3 days before the event, and 31 days to 1 day before the event. The results are robust.
} 
for non-life insurers. Afterwards we form an equally-weighted portfolio for each sub-industry, in which the selected stocks must have at least 30 days with continuous trading three days before FFTR changes.

Table 8 summarizes the regression results for both life and non-life insurers over the period $1988-2007$. The left part presents the regression results for life insurers, and the right side shows those for non-life insurers. Based on $F$-test, we are not able to find evidence that life insurers show any industry-specific risk, whereas the market-model adjusted returns of non-life insurers do react to surprises in FFTR changes. A surprise of 25 basis points cut in FFTR can help non-life insurer's market adjusted stock returns to go up by almost 32 basis points, although the react does not seem to be state-dependent.

As explained in Section 1, insurance companies sell policies and use the written premiums to purchase assets. The distinct reactions of market adjusted returns of these two sub-industries may be explained by their business models. Table 9 summarizes insurance company's net written premiums by product line in 2011, which are the collected premiums minus commissions and reinsurance costs. It is clear that the life insurer's net written premiums mainly (73.71\%) come from long-term policies such as annuities and life policies. Meanwhile, net written premiums of non-life insurers mainly (63.55\%) come from selling shortterm policies such as auto insurance and multiple peril policies. As monetary policy such as changes in FFTR has an immediate impact on the short end of the yield curve, insurance premiums of non-life insurers are inclined to be more sensitive to surprises in FFTR changes.

Similar patterns can be observed by taking a look at the insurance industry asset mix, as presented in Figure 2. It can be seen that $80.60 \%$ of life insurer's total assets are bonds and mortgages. And within the bonds held by life insurers, only $5.71 \%$ are short-term. ${ }^{11}$ This means that life insurers focus on purchasing longterm assets to cover their long-term liabilities in their asset-liability management. Although non-life insurers allocate a majority of their assets in bonds (62.90\%), they also hold a large portfolio of stocks (21.98\% of total assets compared to $3.41 \%$ held by life insurers). ${ }^{12}$ Furthermore, non-life insurers focus more on cash and short-term investment to cover their short-term policies.

11 According to 2009 Life Insurers Fact Book published by American Council of Life Insurers. URL: http://www.acli.com/Tools/Industry\%20Facts/Life\%20Insurers\%20Fact\%20Book/Pages/GR09-\%20215.aspx. Last visited on November 20, 2012.

${ }^{12} \mathrm{We}$ are not able to find information on how many percent of non-life insurer's bonds are short-term. Nevertheless, as noted in Footnote 2, non-life insurers should have a larger portfolio of short-term bonds. 
Table 8 Interest Rate Sensitivity of Insurance Companies over the Period $1988-2007$

\begin{tabular}{|c|c|c|c|c|c|c|c|c|c|c|}
\hline & \multicolumn{5}{|c|}{ Life Insurers (113 Events) } & \multicolumn{5}{|c|}{ Non-life Insurers (114 Events) } \\
\hline & $\mathrm{H} 1$ & $\mathrm{H} 2$ & $\mathrm{H} 3$ & $\mathrm{H} 4$ & H5 & $\mathrm{H} 1$ & $\mathrm{H} 2$ & $\mathrm{H} 3$ & $\mathrm{H} 4$ & H5 \\
\hline \multirow[b]{2}{*}{$\alpha$} & $-1.1 \mathrm{E}-3$ & $-1.0 \mathrm{E}-3$ & $-1.1 \mathrm{E}-3$ & $-1.1 \mathrm{E}-3$ & $-1.1 \mathrm{E}-3$ & $-5.0 \mathrm{E}-4$ & $-4.0 \mathrm{E}-4$ & $-5.0 \mathrm{E}-4$ & $-4.0 \mathrm{E}-4$ & $-4.0 \mathrm{E}-4$ \\
\hline & -1.56 & -1.44 & -1.55 & -1.56 & -1.58 & -1.03 & -0.90 & -1.04 & -0.83 & -0.96 \\
\hline \multirow{2}{*}{$\beta_{u}$} & -0.82 & 1.71 & -1.26 & -1.09 & -0.86 & $-1.27 *$ & 0.61 & -0.47 & -1.29 & $-1.19 *$ \\
\hline & -1.13 & 0.93 & -0.77 & -0.51 & -1.16 & -2.63 & 0.49 & -0.43 & -0.91 & -2.44 \\
\hline \multirow{2}{*}{$\beta_{e}$} & 0.53 & 0.50 & 0.54 & 0.52 & 0.53 & 0.12 & 0.10 & 0.10 & 0.18 & 0.12 \\
\hline & 11.55 & 1.46 & 1.56 & 1.50 & 1.54 & 0.52 & 0.42 & 0.46 & 0.81 & 0.53 \\
\hline \multirow{2}{*}{$\beta_{y}$} & & -2.98 & & & & & -2.21 & & & \\
\hline & & -1.49 & & & & & -1.66 & & & \\
\hline \multirow{2}{*}{$\beta_{d}$} & & & 0.55 & & & & & -1.00 & & \\
\hline & & & 0.30 & & & & & -0.81 & & \\
\hline \multirow{2}{*}{$\beta_{s}$} & & & & 0.31 & & & & & -2.90 & \\
\hline & & & & 0.13 & & & & & -1.93 & \\
\hline \multirow{2}{*}{$\beta_{p}$} & & & & & 1.85 & & & & & -4.75 \\
\hline & & & & & 0.32 & & & & & -1.26 \\
\hline$A d j R^{2}$ & $1.50 \%$ & $2.58 \%$ & $0.68 \%$ & $0.61 \%$ & $0.69 \%$ & $4.39 \%$ & $5.87 \%$ & $4.10 \%$ & $6.67 \%$ & $4.90 \%$ \\
\hline$F$ & 1.85 & 1.99 & 1.25 & 1.23 & 1.26 & $3.59 *$ & $3.35 *$ & 2.61 & $3.69 *$ & $2.94 *$ \\
\hline
\end{tabular}

Note: This table shows the regression results of both life and non-life insurance stocks on unexpected ( $\left.\Delta r^{u}\right)$ and expected ( $\left.\Delta \tilde{r}^{e}\right)$ components of the change in the Federal funds target rate with dummy variables $D_{y}, D_{d}, D_{s}, D_{p}$, to identify the impact of the 1994 change in the way the Federal Reserve announces changes in the funds target rate, the direction of target rate changes, the magnitude of target rate changes, and policy reversal on stock returns. The dummy variable $D_{y}$ is set to 1 if the change happens after February 1994. The dummy variable $D_{d}$ is set 1 if the change is negative. The dummy variable $D_{s}$ is set to 1 if the absolute target rate change is greater than the mean of absolute target rate changes. The dummy variable $D_{p}$ is set to 1 if the change in FFTR represents a policy reversal, and 0 otherwise. The estimates, adjusted $R^{2}$, number of observations ( $n$ ), all estimates, and the F-test for significance of all coefficients are reported. The sample includes 113 events for life insurers and 114 events for non-life insurers. The coefficients are expressed in basis points. * means significance at $95 \%$ confidence interval. 
Table 9 Net Written Premiums of Insurance Companies (As of Year 2011, in Millions)

Panel A: Net Written Premiums of Non-life Insurers (Millions)

\begin{tabular}{l|rrr}
\hline Annuities & $\$$ & 334,821 & $49.50 \%$ \\
Life & $\$$ & 163,770 & $24.21 \%$ \\
Accident and health & $\$$ & 177,837 & $26.29 \%$ \\
\hline Total premiums & $\$$ & 441,632 & $100.00 \%$ \\
\hline Panel B: Net Written Premiums of Life Insurers (Millions) & \multicolumn{3}{l}{} \\
\hline Private/Commercial passenger auto & $\$ 184,364$ & $41.75 \%$ \\
Homeowners/Farm owners/Commercial multiple peril & $\$$ & 96,286 & $21.80 \%$ \\
Workers compensation & $\$$ & 35,667 & $8.08 \%$ \\
The rest & $\$$ & 125,315 & $28.38 \%$ \\
\hline Total premium & $\$$ & 441,632 & $100.0 \%$ \\
\hline
\end{tabular}

Note: This table presents net written premiums of insurance companies as of Year 2011. The premiums are in million US dollar. Panel B is a breakdown of life insurer's net written premiums, and Panel B is that of non-life insurer's net written premiums. (Source: $\quad$ http://www2.iii.org/financial-services-fact-book/insurance/property-casualty/premiums-by-line.html and http://www2.iii.org/financial-services-fact-book/insurance/life-health/premiums-by-line.html. Last visited on November 20, 2012).

Figure 2 Insurance Industry Asset Mix

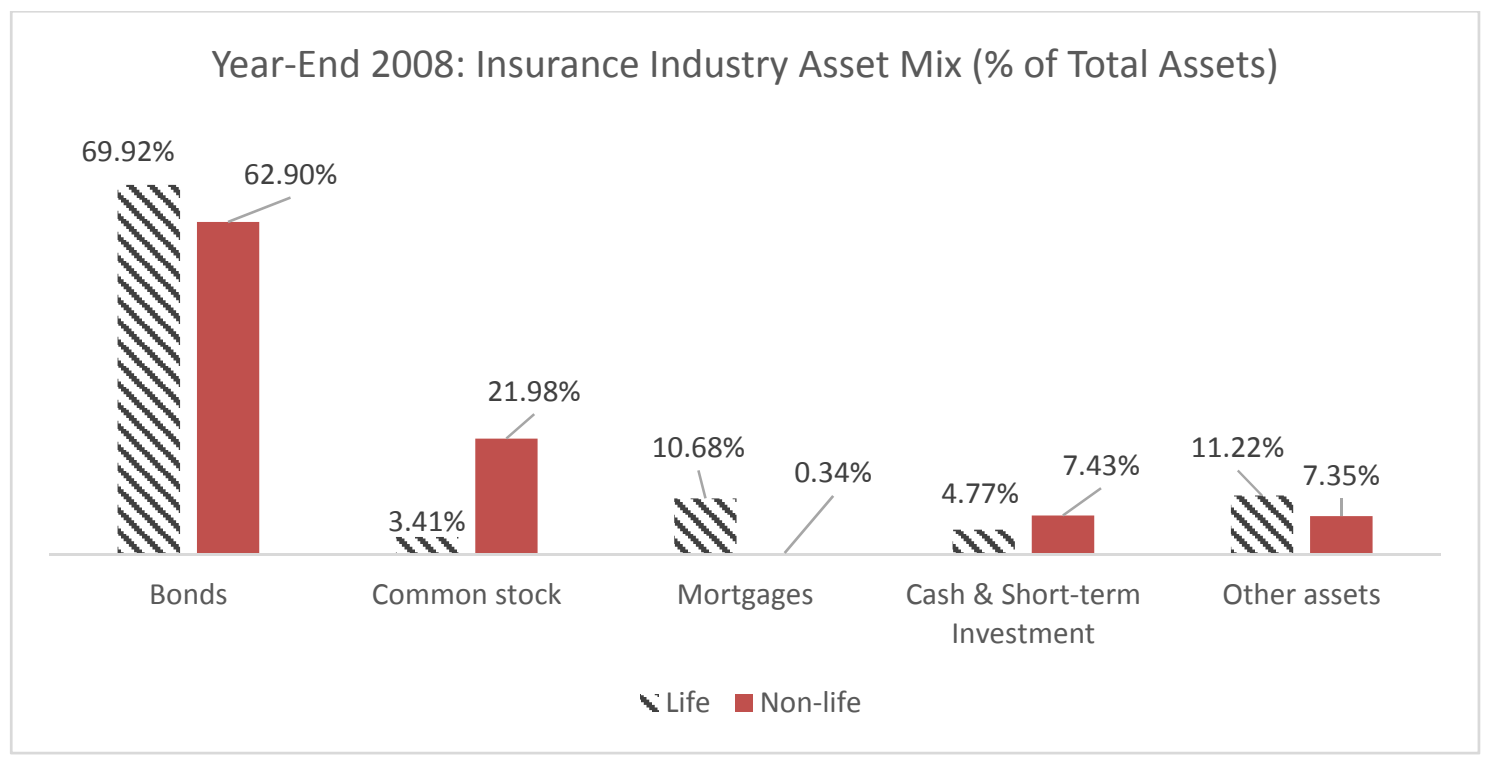

Note: This figure presents insurance industry asset distribution at the end of Year 2008. Data are calculated based on the report of National Association of Insurance Commissioners (http://www.naic.org/capital_markets_archive/110819.htm. Last visited on November 21, 2012).

The different product line and asset distribution of life and non-life insurers implies that they will respond differently to the surprises of yield curve changes. Due to their business model, non-life insurers tend to react to surprises in the short-end of the yield curve, as evidenced by the results in Table 8. 


\section{Conclusion}

In this paper, we study the price reaction of insurance stocks to the expected and unexpected changes in the FFTR over the period 1988-2007. The expected and unexpected changes in the FFTR are derived from the Federal funds futures contracts based on the days of the FOMC meetings or the disclosures of target rate changes. The lack of a precise determination of the FFTR change date leads to fuzzy results for the 19881994 sub-period, which spill over to the 1988-2007 period. The results of the 1994-2007 period, on the other hand, show clear patterns that are consistent over both sub-industries considered. In line with the efficient market hypothesis, expected changes in the Federal fund rate target do not affect the insurer's stock prices. Unexpected changes, however, are consistently negatively related to the stock returns. Especially for life insurance, the effects are strong. There do not seem to be a lot of state dependencies in this relationship. Neither the size of the shock nor the direction of the shock is significantly affecting the interest rate sensitivity caused by unexpected shocks. If we, however, focus on the industry specific risk, we find that only non-life insurers demonstrate industry-specific interest rate risk to surprises in FFTR changes. We conjecture that this market reaction is in accordance with their business model.

\section{References}

Bae, S.C. (1990) Interest rate changes and common stock returns of financial institutions: revisited Journal of Financial Research, 54, 71-79.

Bernanke, B.S. and K.N. Kuttner. (2005) What explains the stock market's reaction to Federal Reserve policy? Journal of Finance, 60, 1221-1257.

Bowman, R.G. (1983) Understanding and conducting event studies, Journal of Business Finance and Accounting, 10, 561-584.

Brewer III, E., J.M. Carson, E. Elyasiani, I. Mansur, and W.L. Scott. (2007) Interest rate risk and equity values of life insurance companies: A GARCH-M model. Journal of Risk and Insurance, 74, 401-423.

CAS Committee on Financial Analysis. (1991) The 'C risk' system of categorizing risks and its possible applicability to the property and casualty industry. Casualty Actuarial Society Forum Casualty Actuarial Society: Arlington, Virginia, 1-6.

Chen, C., N. Mohan, and T. Steiner. (1999) Discount rate changes, stock market returns, volatility, and trading volume: Evidence from intraday data and implications for market efficiency. Journal of Banking and Finance, 23, 897-924.

Chen, C.R. and A. Chan. (1989) Interest rate sensitivity, asymmetry and the stock returns of financial institutions, Financial Review, 24, 457-473. 
Doherty, N.A. and H.B. Kang. (1988) Interest rates and insurance price cycles, Journal of Banking and Finance, 12, 199-214.

Feldblum, S. (1989) Asset liability matching for property/casualty insurers. Casualty Actuarial Society Discussion Paper Program Casualty Actuarial Society: Arlington, Virginia, 117-154.

Flannery, M.J. and M.C. James. (1984) The effect of interest rate changes on the common stock returns of financial institutions. Journal of Finance, 39, 1141-1153.

Giliberto, M. (1985) Interest rate sensitivity in the common stocks of financial intermediaries: a methodological note. Journal of Financial and Quantitative Analysis, 20, 123-126.

Guo, H. (2004) Stock prices, firm size, and changes in the Federal funds rate target. Quarterly Review of Economics and Finance, 44, 487-507.

Haley, J. D. (1993) A cointegration analysis of the relationship between underwriting margins and interest rates: 1930-1989. Journal of Risk and Insurance, 60, 480-493.

Hodes, D.M. and S. Feldblum, S. (1996) Interest rate risk and capital requirements for property/casualty insurance companies. Proceedings of the Casualty Actuaries Society, 83, 490-562.

Krueger, J.T. and K.N. Kuttner. (1996) The Fed funds futures rate as a predictor of Federal Reserve policy. Journal of Futures Markets, 16, 865-879.

Kuttner, K.N. (2001) Monetary policy surprises and interest rates: Evidence from the Fed funds futures market. Journal of Monetary Economics, 47, 523-544.

Kuttner, W. Monetary policy surprises, last visited on December 6, 2010, URL: https://www.sugarsync.com/pf/D64142_026413 79544.

Lee, J. H. and D.R. Stock. (2000) Embedded options and interest rate risk for insurance companies, banks and other financial institutions. Quarterly Review of Economics and Finance, 40, 169-187.

Lobo, B. (2002) Interest rate surprises and stock prices. Financial Review, 37, 73-92.

Morgan Stanley Capital International. Global Industry Classification Standard (GICS), last visited on November 4, 2010, URL: http://www.mscibarra.com/resources/pdfs/MK-GICS-DIR-3-02.pdf.

Nosal, E. (2001) How well does the Federal Funds futures rate predict the future Federal Funds rate? Economic Commentary: Federal Reserve Bank of Cleveland.

Poole, W. and R.H. Rasche. (2003) The impact of changes in FOMC disclosure practices on the transparency of monetary policy: are markets and the FOMC better 'synched'? Federal Reserve Bank of St. Louis Review, 85, 1-10.

Poole, W., R.H. Rasche and D.L. Thornton. (2002) Market anticipations of monetary policy actions. Federal Reserve Bank of St. Louis Review, 84, 65-94.

Staking, K. and D. Babbel. (1995) The relation between capital structure, interest rate sensitivity, and market value in the property-liability insurance industry. Journal of Risk and Insurance, 62, 690-718. 
Stone, B.K. (1974) Systematic interest-rate risk in a two-index model of returns. Journal of Financial and Quantitative Analysis, 9, 709-721.

Santomero, A.M. and D.F. Babbel. (1997) Financial risk management by insurers: an analysis of the process. Journal of Risk and Insurance, 64, 231-270.

Yin, H., J. Yang. and W.C. Handorf. (2010) State dependency of bank stock reaction to Federal funds target rate changes. Journal of Financial Research, 33, 289-315. 